\begin{tabular}{|c|c|c|}
\hline \multirow[b]{2}{*}{ EVCDI I ENT } & Int.J.Curr.Microbiol.App.Sci (2021) 10(08): 9-18 & \\
\hline & $\begin{array}{l}\text { International Journal of Current Microbiology and Applied Sciences } \\
\text { ISSN: 2319-7706 Volume } \mathbf{1 0} \text { Number } 08 \mathbf{( 2 0 2 1 )} \\
\text { Journal homepage: } \underline{\mathrm{http}: / / \text { www.ijcmas.com }}\end{array}$ & 89 \\
\hline PUBLISHERS & & www.ijcmas.com \\
\hline
\end{tabular}

Original Research Article

https://doi.org/10.20546/ijcmas.2021.1008.002

\title{
Comparison of Multiplex Polymerase Chain Reaction and Culture for Diagnosis of Acute Bacterial Meningitis
}

\author{
Sanjana Upadhyay*, Anil Kumar Bilolikar and Sukrutha Gopal Reddy \\ Department of Laboratory Medicine, Krishna Institute of Medical Sciences, Minister Road, \\ Secunderabad - 500003, Telangana, India \\ *Corresponding author
}

\section{A B S T R A C T}

\begin{tabular}{|l|}
\hline Ke y w or d s \\
CSF, \\
multiplex PCR, \\
culture, \\
Vitek 2 compact \\
\hline Article Info \\
\hline $\begin{array}{l}\text { Accepted: } \\
\text { 10 July } 2021 \\
\text { Available Online: } \\
10 \text { August } 2021\end{array}$ \\
\hline \hline
\end{tabular}

Bacterial meningitis remains a serious global health problem. The laboratory plays a crucial role in diagnosing this devastating disease. It is a medical emergency that requires early rapid diagnosis to establish the specific cause for effective antimicrobial therapy. To detect and compare the etiological agents in suspected cases of bacterial meningitis by conventional culture and multiplex PCR. CSF examination was done macroscopically and microscopically (Gram stain). Biochemical analysis and cell counts were also performed followed by conventional culture using BacT/ALERT 3D Microbial Detection System and VITEK 2 COMPACT for identification and antimicrobial susceptibility testing and multiplex PCR. Bacterial growth was detected in 45 CSF samples by culture and multiplex PCR together. With bacterial culture as gold standard method, the sensitivity, specificity, positive predictive value and negative predictive value of multiplex PCR were $85.7 \%, 76.7 \%, 37.5 \%$ and $97.05 \%$ respectively. Multiplex PCR is a rapid and sensitive test for the diagnosis of bacterial meningitis. The use of molecular techniques (PCR) can provide a valuable addition in cases with high rates of culture-negative results i.e, those with administration of antibiotics prior to lumbar puncture.

\section{Introduction}

Bacterial meningitis remains a serious global health problem. The laboratory plays a crucial role in diagnosing this devastating disease ${ }^{1}$. It is a medical emergency that requires early rapid diagnosis to establish the specific cause for effective antimicrobial therapy ${ }^{2}$. Bacterial meningitis is a severe infection of the meninges and cerebrospinal fluid (CSF) surrounding the brain and spinal cord, associated with substantial morbidity and mortalityrates worldwide ${ }^{3}$. The patients following hospital discharge has around 20\% risk of developing neurological sequelae including hearing loss, seizures, behavioral changes and mentalretardation ${ }^{4}$. The development of polysaccharide and conjugate 
vaccines has reduced the incidence of bacterial meningitis, still around 1.2 million cases known to occur each year worldwide ${ }^{5}$. In India among children and adults, Streptococcus pneumoniae ( $S$. pneumoniae) is the predominant pathogen to cause bacterial meningitis followed by Haemophilus influenzae (H. influenzae) and Neisseria meningitidis ( $N$. meningitidis). The mortality rate due to acute bacterial meningitis is 16$32 \%$ despite potent antibiotictreatment ${ }^{6}$.

The clinical symptoms of bacterial meningitis ranges from fever, headache, meningismus to altered consciousness including confusion, delirium, lethargy and coma. The typical triad of fever, neck rigidity and altered mental state is seen in only two-thirds of the patients ${ }^{7}$.

The risk factors include diabetes mellitus, alcoholism, cancer, immunosuppressive therapy, human immunodeficiency virus (HIV) infection ${ }^{8}$.

The spectrum of laboratory investigations for suspected cases of bacterial meningitis ranges from direct microscopy of CSF sample to molecular methods like Polymerase Chain Reaction (PCR). The basic investigations include Gram stain, culture, cytological and biochemical evaluation of the CSF sample ${ }^{9}$.

CSF culture is considered to be the gold standard investigation in the diagnosis of bacterial meningitis. It is found to be less efficacious due to its high turnaround time (>48 hours) and low bacterial growth rate particularly in patients who have received antibiotics before sample collection and due to improper storage, transportation conditions and culture practices ${ }^{10}$. Since microbiological identification is not available readily, empirical treatment should be considered based on regional antibiotic resistance pattern, patient age, predisposing factors andresources $^{11}$.
The culture negative CSF samples can be analyzed by molecular methods such as multiplex PCR which can detect even small amounts of non viable pathogen DNA within a few hours (24 hours) ${ }^{12}$. It can complement and confirm the results of conventional culture methods.

The purpose of this study is to estimate the prevalence of bacterial meningitis in patients admitted to the Krishna Institute of Medical Sciences, Secunderabad, Telangana, India. Detect and compare the etiological agents between culture and PCR. Identify the most common bacteria causing meningitis. Age group and gender affected and Associated risk factors.

\section{Materials and Methods}

A prospective and observational study was conducted at the Department of Microbiology and Molecular Biology, Krishna Institute of Medical Sciences, Minister Road, Secunderabad, Telangana, India from September 2018toAugust 2019. The study was approved by the scientific committee of the institute. A structured proforma including patient information sheet was used to record clinical and demographic data.

\section{Inclusion criteria}

Patients belonging to all age groups, both male and female clinically suspected of having bacterial meningitis with or without risk factors like recent head injury or neurosurgery were eligible. The symptoms were acute onset of fever (usually > $38.5{ }^{\circ} \mathrm{C}$ rectal or $38.0{ }^{\circ} \mathrm{C}$ axillary), headache and signs were neck stiffness, altered consciousness or other meningeal signs suggestive of acute pyogenic meningitis. Patients samples were included in further analyses if the CSF examination showed at least one of the following: - 
Turbid appearance

Leukocytosis (> 100 cells/mm3).

Leukocytosis (10-100 cells/mm3) and either an elevated protein $(>45 \mathrm{mg} / \mathrm{dl})$ or decreased glucose $(<40 \mathrm{mg} / \mathrm{dl})^{13}$

Patients with clinical features suggestive of tuberculous, viral and fungal meningitis were excluded from the study. The written and informed consent was obtained from the legal guardian in case of paediatric patients.

Sample collection, transport and processing

CSF samples were collected aseptically by an experienced medical officer and delivered to the laboratory immediately with a complete request form including patients details and clinical condition. The samples were processed as soon as possible.

Preliminary examination of CSF was done macroscopically followed by Gram stain, biochemical analysis and cell counts.

\section{Culture of CSF}

The inoculation of CSF sample was done in BacT/ALERT FA Plus culture bottle inside Biosafety Cabinet II, taking safety precautions to avoid contamination. The BacT/ALERT culture bottles were loaded into the BacT/ALERT 3D Microbial Detection System. When the inoculated BacT/ALERT FA Plus culture bottle flagged positive, they were unloaded and sub cultured on blood agar (BA), MacConkey agar (MA), chocolate agar (CA) and fluid thiogycollate medium (FTM). The blood agar, chocolate agar and FTM were incubated in a $5-10 \% \quad \mathrm{CO} 2$ enriched atmosphere at $35-37^{\circ} \mathrm{C}$ for $24-48 \mathrm{hrs}$ and checked for growth after overnight incubation. The MacConkey agar plate was incubated aerobically at $35-37^{\circ}$ Covernight.
Identification and antimicrobial susceptibility testing (AST) of bacteria was done by using VITEK 2 compact(BIOMERIEUX). The identification cards -GN, GP and AST cards N280, N281, P628, ST03 were used. Quality control strains were also tested. The Clinical and Laboratory Standards Institute (CLSI) guidelines 2018 and 2019 were followed for reporting,

\section{Molecular method byMultiplex Polymerase Chain Reaction}

The PCR can detect the following organisms Staphylococcus species (S. aureus, S.epidermidis, S. haemolyticus), Streptococcus pneumoniae, Streptococcus agalactiae, Enterococcus species, Listeria monocytogenes, E. coli, Klebsiella pneumoniae, Pseudomonas aeruginosa, Acinetobacter baumannii and Neisseria meningitides.

PCR involves ${ }^{14}$ DNA extraction using QIA cube (QIAGEN) followed by amplification.

The positive, negative and internal controls were used according to the specifications mentioned in the kit protocol issued by the manufacturer.

\section{Results and Discussion}

During this period a total of 495 CSF samples were received in the laboratory for Culture and Sensitivity testing. As the study focuses on the comparison of aerobic culture and multiplex PCR, the CSF samples received for both the investigations were included. A total of $50 \mathrm{CSF}$ samples during this time period received in the Molecular Biology laboratory for Multiplex PCR were analyzed. Hence 50 samples for Multiplex PCR and culture were analyzed. 
There were $35(70 \%)$ males and $15(30 \%)$ females. There was male predominance observed compared to female. Maximum number of patients were observed in the age group 21-30 years (20\%), 51-60 years (20\%), followed by $31-40$ years (14\%), 41-50 years (14\%), 0-10 years $(12 \%)$ and $61-70$ years (10\%). Majority CSF samples were received from Neurology (78\%) followed by Pediatrics $(10 \%)$, Neurosurgery (8\%) and Medicine(4\%).

In the study, 28 patients were found to have risk factors. Most common of them were Hypertension (HTN), Diabetes mellitus (DM), Ventriculo-Peritoneal (VP) shunt, Road traffic accident (RTA) and Autoimmune disorders. However in some patients these were observed as incidental findings which could be attributed as risk factors. No risk factors were observed in 22 patients.

Prevalence of bacterial meningitis- A total of 495 CSF samples were received in the Microbiology laboratory for culture and sensitivity testing. Bacterial growth was detected in 45 CSF samples. In the present study, the prevalence $\left(45^{*} 100 / 495\right)$ observed was $9.09 \%$.

With bacterial culture as gold standard method, the sensitivity, specificity, positive predictive value and negative predictive value of multiplex PCR were 85.7\%, 76.7\%, 37.5\% and $97.05 \%$ respectively.

Interpretive categories for Minimal Inhibitory Concentrations (MICs) were according to CLSI guidelines $2018^{15}$.

Acute bacterial meningitis is a life threatening condition, known to cause huge mortality and long-term neurological sequelae. ${ }^{6}$ So prompt and accurate diagnosis of the pathogen and initiation of early treatment is essential for favourable clinical outcome. ${ }^{16}$
The present study involved a total of $50 \mathrm{CSF}$ samples with presumptive diagnosis of meningitis were analyzed for comparison between bacterial culture and multiplex PCR.

This study details that most cases of meningitis were in the age group 20-60 years. Mean age was 39.86 years, similar to the study done by Khater and Elabd ${ }^{17}$. Contrary to this, study done by Seth et al., ${ }^{18}$ and Mahdi et al., ${ }^{19}$, mean age was 14.5 years and 9.46 years as they included pediatric population in their study.

In this study it was also found that bacterial meningitis occur more in males than in females. The males $(35,70 \%)$ were significantly more than females $(15,30 \%)$, with male to female ratio of 2.3:1. Similar results were observed by Mahdi et al., ${ }^{19}$ (ratio 2.7:1) and Khater et al., ${ }^{17}(2.07: 1)$.

In the present study, the PCR assay has identified more bacterial isolates (32\%) than culture (14\%). The low percentage of bacterial culture positives may be due to other possible factor such as prior administration of antibiotics before lumbar puncture (LP). Similar observations were seen in studies done by - Mashal Khan et al., ${ }^{2}$, Wu et al., ${ }^{20}$, Mahdi ZK et al. ${ }^{19}$, Wang et al., ${ }^{21}$, Yahia MA et al., ${ }^{13}$ and Sarookhani et al., ${ }^{22}$. However, in a study conducted by Seth et al., ${ }^{18}$, bacterial culture positives were more compared to PCR positives as in their PCR panel, primers of only few organisms namely $S$. pneumoniae, $N$. meningitidis, $H$. influenzae were present. The diagnostic accuracy of multiplex PCR by keeping bacterial culture as gold standard including sensitivity, specificity, PPV and NPV in the present study was $85.7 \%, 76.7 \%$, $37.5 \%$ and $97.05 \%$ respectively implying high sensitivity, high NPV, low specificity and low PPV comparatively. This finding was similar to Wang etal ${ }^{21}$ (sensitivity $80 \%$, specificity 76.4\%, PPV 25\%, NPV 97.5\%), Mahdi et 
al., ${ }^{19}$ (sensitivity $100 \%$, specificity $60.64 \%$, PPV

13.93\%, NPV 100\%) and Sarookhani et al., ${ }^{22}$ (sensitivity 100\%, specificity 40.6\%,PPV 48.6\%, NPV 100\%).

In the present study, the Gram positive organisms(10) were found to be more compared to Gram negative organisms (7) in causing bacterial meningitis. It was also observed in other studies ${ }^{21,13}$. S. pneumoniae (3), S. aureus (3), Group B streptococcus spp. (GBS-2, S. agalactiae-1) followed by $N$. meningitidis (2), $K$. pneumoniae (2) were the common organisms isolated. Single isolates each of L. monocytogenes, E. coli, $P$. aeruginosa and $A$. lwoffii were also detected.

S. pneumoniae (17.6\%) was one of the common etiological agents. The finding was similar to Chakrabarti P et al., ${ }^{23}$, who reported only two cases of pneumococcal meningitis. $\mathrm{R}$ Mani et al., ${ }^{6}$ reported S. pneumoniae in 238 CSF samples and Mahdi et al., ${ }^{19}$ reported $S$. pneumoniae in $43 \mathrm{CSF}$ samples which was in contrast to finding in this study as there were very few children below 2 years of age.

Though $S$. pneumoniae is mostly seen as a causative agent of meningitis in pediatric age group, however in the present study, there were 3 cases of $S$. pneumoniae in the adult age group which is a contrasting observation. The reason for this can be surgical intervention (meningioma/ VP shunt) which can cause breaching of such organisms into the intracerebral areas.

The next isolate among Gram positive organisms was $S$. aureus $(17.6 \%)$ which were found in three CSF samples, wherein two CSF samples were from the pediatric age group (7years \& 8 years) and one CSF sample from 64 year old male. The causative factor for $S$. aureus isolation in pediatric patients can be due to presence of hydrocephalus with surgical intervention (VP shunt). However, in the adult patient the reason could not be ascertained, probably due to association of comorbid conditions i.e, DM and HTN. These findings were similar to the study done by Seth et al., ${ }^{18}$, R Mani et al., ${ }^{6}$ and Wang etal ${ }^{21}$.

Another peculiar finding in the present study was the isolation of Group B Streptococcus $(G B S)$ in the adult patients, though it is a common cause of neonatal meningitis. Here, Group B Streptococcus spp. $(17.6 \%)$ has been detected in three CSF samples (age-22years, 26years, 35years) with no identifiable risk factors. This was similar to study done by Wilder-Smith et al., ${ }^{24}$ and Domingo et al., ${ }^{25}$ where they reported Group B streptococcal meningitis in adults.

A case of L. monocytogenes (5.8\%) was detected in a 8 year old female patient who presented with febrile seizures. Detailed history revealed consumption of unpasteurised milk. The isolation of L.monocytogenes was seen in study done by Wangetal ${ }^{21}(7.14 \%)$. Other studies by Yahia MA et al., ${ }^{13}$ (11.7\%) and Favaro et al., ${ }^{26}$ (24.4\%) had higher prevalence, whereas Boving et al., ${ }^{27}$ (1.8\%) and Chiba et al., ${ }^{28}(0.8 \%)$ had lower prevalence.

In the present study Gram negative organisms (\%) were also detected. Meningococcal meningitis $(11.7 \%)$ was detected in two CSF samples of adult patients. This finding was similar to Chinchankar N et al., ${ }^{29}$, Seth et al., ${ }^{18}$ and R Mani et al., ${ }^{6}$. This data shows very low prevalence of meningococcal meningitis in Indian setting which could be due to the fact that it is a fastidious organism and also the introduction of widespread immunization and chemoprophylaxis in the high risk population. 
Table.1 Comparison of CSF culture and multiplex PCR

\begin{tabular}{|c|c|c|c|c|}
\hline Group & $\begin{array}{c}\text { Group I: Culture + } \\
\text { Multiplex PCR+ }\end{array}$ & $\begin{array}{c}\text { Group II: } \\
\text { Culture + } \\
\text { Multiplex PCR - }\end{array}$ & $\begin{array}{c}\text { Group III: } \\
\text { Culture - } \\
\text { Multiplex PCR + }\end{array}$ & $\begin{array}{c}\text { GroupIV: } \\
\text { Culture- } \\
\text { Multiplex PCR- }\end{array}$ \\
\hline $\begin{array}{l}\text { Number }(\mathbf{n}) \\
\text { of sample } \\
\text { received }(\%)\end{array}$ & $\mathrm{n}=6(12 \%)$ & $1(2 \%)$ & $10(20 \%)$ & $33(66 \%)$ \\
\hline \multirow[t]{5}{*}{$\begin{array}{l}\text { Bacteria } \\
\text { isolated }\end{array}$} & $\begin{array}{c}\text { Klebsiella } \\
\text { pneumoniae (2) }\end{array}$ & $\begin{array}{c}\text { Acinetobacter } \\
\text { lwoffii* } *(1)\end{array}$ & $\begin{array}{c}\text { Group B } \\
\text { Streptococcus (2) }\end{array}$ & - \\
\hline & $\begin{array}{l}\text { Pseudomonas } \\
\text { aeruginosa (1) }\end{array}$ & & $\begin{array}{l}\text { Streptococcus } \\
\text { agalactiae (1) }\end{array}$ & \\
\hline & $\begin{array}{c}\text { Staphylococcus } \\
\text { aureus (1) }\end{array}$ & & $\begin{array}{c}\text { Staphylococcus } \\
\text { aureus (2) }\end{array}$ & \\
\hline & $\begin{array}{c}\text { Streptococcus } \\
\text { pneumoniae (1) }\end{array}$ & & $\begin{array}{c}\text { Streptococcus } \\
\text { pneumoniae (2) }\end{array}$ & \\
\hline & $\begin{array}{c}\text { Listeria } \\
\text { monocytogenes (1) }\end{array}$ & & $\begin{array}{l}\text { Escherichia coli } \\
\text { (1) } \\
\text { Neisseria } \\
\text { meningitidis (2) }\end{array}$ & \\
\hline
\end{tabular}

(+: Detected, -: Not detected)

* In multiplex PCR, there is a probe for detection of Acinetobacter baumannii but not Acinetobacter lwoffii, hence it was not detected.

Fig.1 Vitek 2 compact system with reader-incubator, a computer control module, a data terminal, and a multicopy printer.

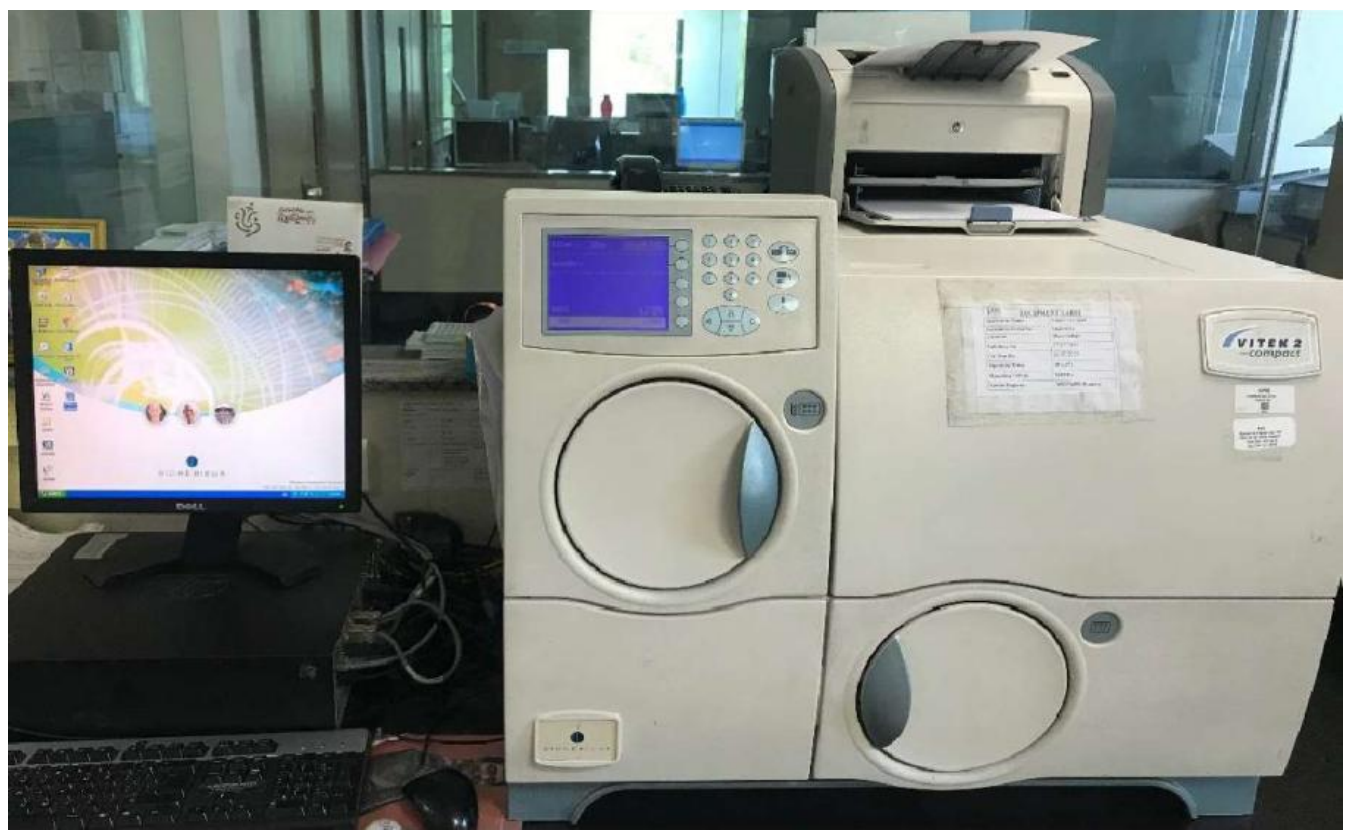


Fig.2 Pie diagram showing Department wise distribution

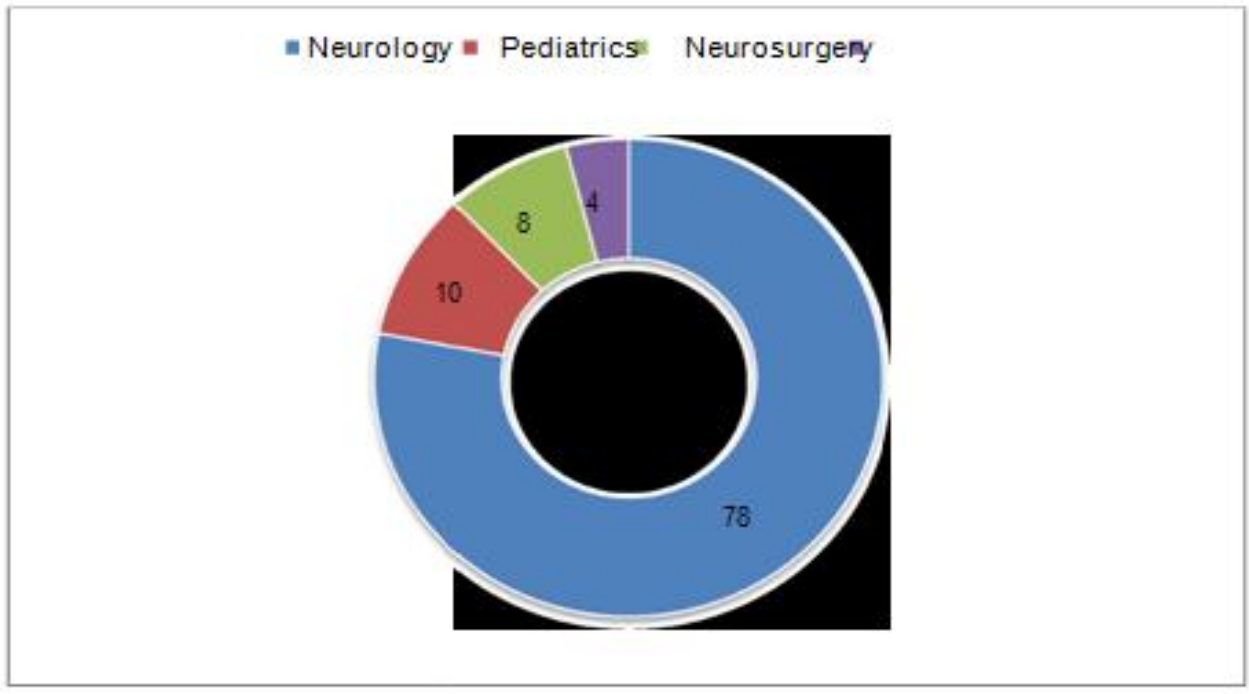

Fig.3 Graphical representation of risk factors

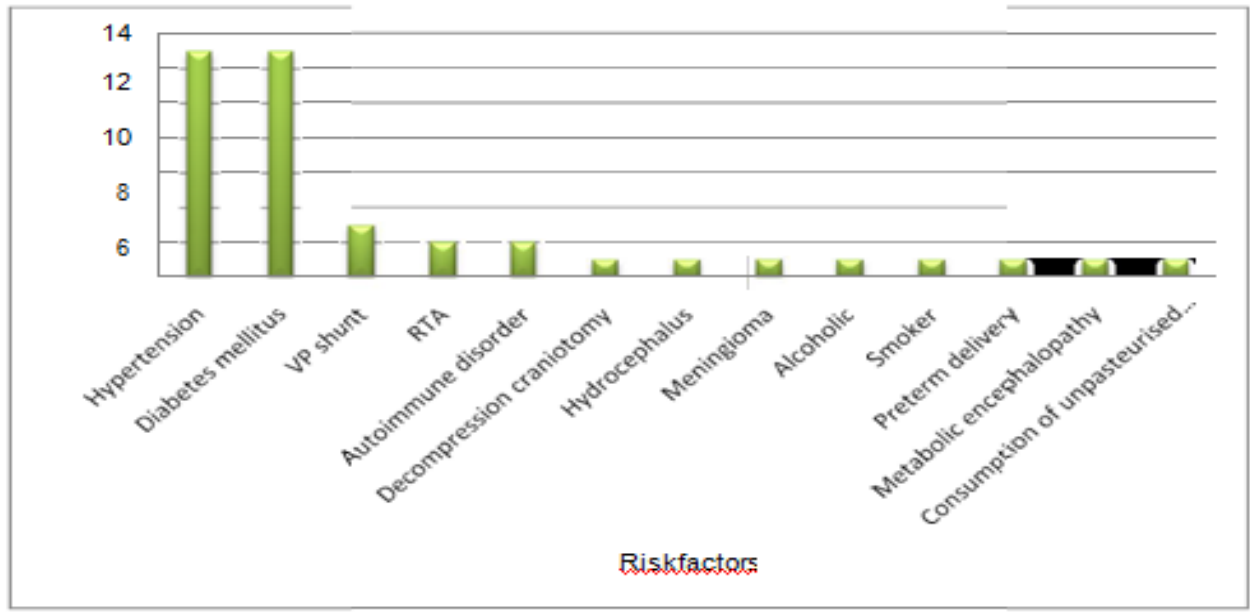

Fig.4 L. monocytogenes showing narrow zone of beta hemolysis on Blood agar

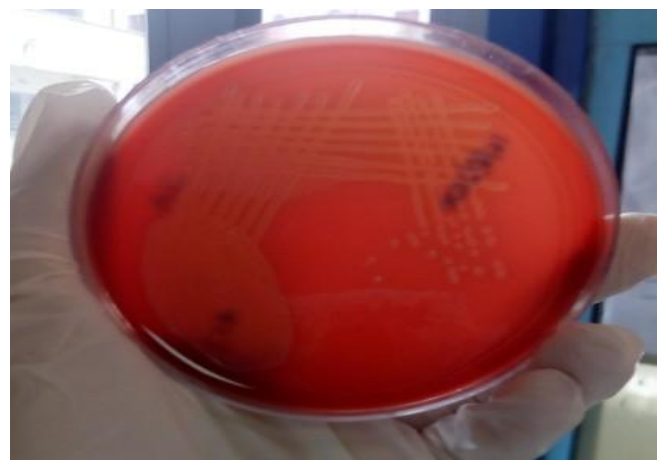


H. influenzae was not detected in our study. It could be due to introduction of routine Hib vaccine against $H$. influenzae as a part of universal immunization schedule and herd immunity of the vaccine administered to other children. Very few cases of $H$. influenza meningitis had been observed in otherstudies. ${ }^{6,18,23}$.

Among Enterobacteriaciae, 2 cases of $K$. pneumoniae and a single isolate of $E$. coli was detected. In non-fermentative gram negative organisms, single case of P.aeruginosa and $A$. lwoffii was detected. The emergence of these GN organisms as the causative agent of bacterial meningitis especially in elderly and in patients with immunocompromised conditions like head injuries (RTA), neurosurgical procedures (Decompression craniotomy, VP shunt) and underlying disesase like carcinoma, diabetes, hypertension is recently recognized. This observation of changing trends was also seen in studies done by Chakrabarti et $a l .{ }^{23}$ and Seth et al., ${ }^{18}$.

The prevalence of meningitis in the present study was found to be $9.09 \%$. It was similar to Wagner K et al., ${ }^{16}(9.09 \%)$ and Dunne EM $\mathrm{etal}^{30}(17.67 \%)$. There were other studies with higher prevalence - Wu et al., ${ }^{20}$ (25.94\%), Seth et al., ${ }^{18}$ (31.2\%), Mahdi et al., ${ }^{19}$ (43\%), Wang et al., ${ }^{21}$ (50\%). Reason for this higher prevalence could be huge sample size and pediatric population. Based on the present study the interpretation is multiplex PCR is more sensitive in detecting bacterial isolates compared to culture in suspected cases of bacterial meningitis. However, the PCR cannot perform AST, hence the CSF samples should be sent to laboratory for processing by both the methods i.e, culture and multiplex PCR.

\section{Limitation}

The AST profile of some organisms could not be performed. The sample size of CSFs positive for the pathogens in this study wassmall.PCR cannot provide susceptibility pattern of the detected isolates. Only two methods i,e. culture and multiplex PCR are compared. Follow up of the patients was not done.

Multiplex PCR is a rapid and sensitive test for the diagnosis of bacterial meningitis. However, conventional bacterial culture can be still considered as a gold standard method as it provides identification as well as susceptibility pattern of the bacterial isolates and PCR can be used as a supplementary method. The use of molecular techniques (PCR) can provide a valuable addition in cases with high rates of culture-negative results i.e, those with administration of antibiotics prior to LP. The performance characteristics of the conventional culture and multiplex PCR highlights the use of both the methods particularly in suspicious contaminated samples, presence of fastidious or slow growing bacteria and antibiotic usage.

\section{Recommendation}

More studies with large sample size should be done. Methods like Gram stain, Latex agglutination test should also be compared with the conventional culture and multiplex PCR. Empirical treatment can be initiated based on hospitals Antimicrobial Stewardship Policy. Microbroth dilution facility should be available for certain organisms.

\section{Financial Support}

This work was supported by Department of Microbiology and Molecular Biology, Krishna Institute of Medical Sciences, Minister Road, Secunderabad, Telangana, India.

\section{Acknowledgements}

The author, Dr Sanjana Upadhyay, 
acknowledges Department of Microbiology and Molecular Biology, Krishna Institute of Medical Sciences, Minister Road, Secunderabad, Telangana, India.

\section{References}

1. CDC. Introduction. 2012; Chapter 01:01.

2. Khan M, Khan K M A, Pardhan K, Memon A A. Identification of etiological agents by LPA and PCR in childhood meningitis. PakJMedSci.2013;29(5):1162-1166.

3. Diawara I, Katfy K, Zerouali K, Belabbes $\mathrm{H}$, Elmdaghri Net al., A duplex real-time PCR for the detection of Streptococcus pneumoniae and Neisseria meningitidis in cerebrospinal fluid. J Infect Dev Ctries. 2016;10(1):053-061.

4. Edmond K, Clark A, Korczak VS, Sanderson C, Griffiths U K, Rudan I. Global and regional risk of disabling sequelae from bacterial meningitis: a systematic review and metaanalysis. Lancet Infect Dis.2010;10:317-28.

5. CDC. Epidemiology of meningitis caused by Neisseria meningitidis, Streptococcus pneumoniae, and Haemophilus influenzae. 2012; Chapter 2:01-08.

6. Mani R, Pradhan S, Nagarathna S, Wasiulla $\mathrm{R}$, Chandramuki A. Bacteriological profile of community acquired acute bacterial meningitis: a ten-year retrospective study in a tertiary neurocare centre in South India. Indian J Med Microbiol. 2007;25(2):10814.

7. Durand M L, Calderwood S B, Weber D J, Miller S I, Southwick F S, Caviness V S et al., Acute bacterial meningitis in adults: A review of 493 episodes. $\mathrm{N}$ Engl J Med. 1993;328(1):21-28.

8. Brouwer M C, Tunkel A R, Van de Beek D. Epidemiology, diagnosis and antimicrobial treatment of acute bacterial meningitis. ClinMicrobiol Rev.2010;23(3):467-492.

9. Van de Beek D, Brouwer M C, Thwaites G $\mathrm{E}$, Tunkel A R. Advances in treatment of bacterial meningitis. Lancet.2012;380:1693-1702.
10. CDC. PCR for Detection and characterization of bacterial meningitis pathogens: Neisseria meningitidis, Haemophilus influenzae and Streptococcus pneumoniae. 2012; Chapter 10:01-56.

11. Hoffman O, Weber R J. Pathophysiology and treatment of bacterial meningitis. Ther Adv NeurolDisord. 2009Nov;2(6):1-7.

12. Meyer $\mathrm{T}$, Franke $\mathrm{G}$, Polywka $\mathrm{S} K \mathrm{~K}$, Lutgehetman M, Gbadamosi J, Magnus T et al., Improved detection of bacterial central nervous system infections by use of a broad- range PCR assay. J ClinMicrobiol.2014;52(5):1751-1753.

13. Yahia M A, Balach O. Comparison of multiplex PCR, Gram stain, and culture for diagnosis of acute bacterial meningitis. Int $\mathbf{J}$ Pharm PharmSci.2014;6(6):425-429.

14. Sambrook J, Russel D W. Molecular Cloning: A Laboratory Manual: In vitro Amplification of DNA by the Polymerase Chain Reaction. $3^{\text {rd }}$ edition. New York: Cold SpringHarbor;2001:4-6.

15. Clinical and Laboratory Standards Institute (CLSI). Performance Standards for antimicrobial susceptibility testing. $28^{\text {th }}$ edition. CLSI supplement. M100. Wayne, IN. 2018.

16. Wagner K, Springer B, Pires V P, Keller P M. Pathogen identification by multiplex LightMix Real-Time PCR assay in patients with meningitis and culture-negative cerebrospinal fluid specimens. J ClinMicrobiol. 2018; 56(2):01-08.

17. Khater W S, Elabd S H. Identification of common bacterial pathogens causing meningitis in culture-negative cerebrospinal fluid samples using Real-Time Polymerase Chain Reaction. Int J Microbiol. 2016;2016(4197187):01-05.

18. Seth R, Murthy P S R, Sistla S, Subramaian M, Tamilarasu K. Rapid and accurate diagnosis of acute pyogenic meningitis due to Streptococcus pneumoniae, Haemophilus influenzae Type $\mathrm{b}$ and Neisseria meningitidis using a multiplex PCR assay. J ClinDiagn Res. Sep 2017;11(9):01-04(1).

19. Mahdi Z K, Al-Momen H H, Obed A A, Al-Zwaini E J. Polymerase Chain Reaction 
testing in comparison to culture of cerebrospinal fluid for diagnosis of bacterial meningitis in children. Karbala J Med. June 2018;11(1):3903-3911.

20. $\mathrm{Wu} \mathrm{H} \mathrm{M}$, Cordeiro S M, Harcourt BH, Carvalho M G S, Azevedo J, Oliveira TQ et al., Accuracy of real-time PCR, Gram stain and culture for Streptococcus pneumoniae, Neisseria meningitidis and Haemophilus influenzae meningitis diagnosis. BMC Infectious Diseases.2013;13(26):01-10.

21. Wang Y, Guo G, Wang H, Yang X, Shao F, Yang $\mathrm{C}$ et al., Comparative study of bacteriological culture and real-time fluorescence quantitative PCR (RT-PCR) and multiplex PCR-based reverse line blot (mPCR/RLB) hybridization assay in the diagnosis of bacterial neonatal meningitis. BMC Pediatrics.2014; 14(224):01-08.

22. Sarookhani M R, Ayazi P, Alizadeh S, Foroughi F, Sahmani A, Adineh M et al., Comparison of $16 \mathrm{~S}$ rDNA-PCR amplification and culture of cerebrospinal fluid for diagnosis of bacterial meningitis. Iran J Pediatr. 2010; 20(4):471-475.(2)

23. Chakrabarti P, Das B K, Kapil A. Application of $16 \mathrm{~S}$ rDNA based seminested PCR for diagnosis of acute bacterial meningitis. Indian J Med Res.2009;129(2):182-88.

24. Wilder-Smith E, Chow K M, Kay R, Ip M, Tee N. Group B Streptococcal meningitis inadults:Recent increase in South east Asia.
AustNZJMed.2000;30:462-5.

25. Domingo P, Barquet N, Alvarez M, Coll P, Nava J, Garau J. Group B Streptococcal meningitis in adults: Report of twelve cases and review. Clin Infect Dis. 1997;25:11807.

26. Favaro M, Savini V, Favalli C. A MultiTarget Real-Time PCR Assay for rapid identification of meningitis- associated microorganisms. MolBiotechnol. 2013Jan;53(1):74-9.

27. Boving M K, Pedersen L N, et al., Eightplex PCR and liquid-array detection of bacterial and viral pathogens in cerebrospinal fluid from patients with suspected meningitis. J ClinMicrobiol. 2009Apr;47(4):908-13.

28. Chiba N, Murayama S Y, et al., Rapid detection of eight causative pathogens for the diagnosis of bacterial meningitis by real-time PCR. J Infect Chemother. 2009 January;15:92-98.

29. Chinchankar N, Mane M, Bhave S, Bapat S, Bavdekar A, Pandit A, et al., Diagnosis and outcome of acute bacterial meningitis in early childhood. Indian Pediatr. 2002;39:914-21.

30. Dunne E M, Mantanitobua S, Singh S P, Reyburn R, Tuivaga E, Rafai E et al., Realtime qPCR improves meningitis pathogen detection in invasive bacterial-vaccine preventable disease surveillance in Fiji. Sci Rep.2016;6(39784):1-7.

\section{How to cite this article:}

Sanjana Upadhyay, Anil Kumar Bilolikar and Sukrutha Gopal Reddy. 2021. Comparison of Multiplex Polymerase Chain Reaction and Culture for Diagnosis of Acute Bacterial Meningitis. Int.J.Curr.Microbiol.App.Sci. 10(08): 9-18. doi: https://doi.org/10.20546/ijcmas.2021.1008.002 